\title{
СОЦИАЛЬНО-ЭКОНОМИЧЕСКИЕ ПРЕДПОСЫЛКИ ТРАНСФОРМАЦИИ ПАРАДИГМЫ УПРАВЛЕНИЯ
}

\section{SOCIO-ECONOMIC BACKGROUND OF THE TRANSFORMATION \\ OF THE PARADIGM OF MANAGEMENT}

\section{A. Ozina}

A. Buzmakova

A. Khachatryan

Summary: The article examines the socio-economic prerequisites for the transformation of the management system, presents the evolution of the term «management».

Keywords: management paradigm, organization, schools of scientific management, transformation of the management paradigm.
Озина Альбина Михайловна

Д.э.н., академик РАEH, профессор, Нижегородский институт управления - филиал РАНХиГС al.ozina@mail.ru

Бузмакова Алёна Николаевна Аспирант, Нижегородский институт управления - филиал РАНХиГС a.n.buzmakova@mail.ru

Хачатрян Аревик Врежовна Аспирант, Нижегородский институт управления - филиал РАНХИГС arevik_hachatryan@mail.ru

Аннотация: В статье рассмотрены социально-экономические предпосылки преобразования системы управления, представлена эволюция термина «управление».

Ключевые слова: парадигма управления, организация, школы научного управления, трансформация парадигмы управления.

В процессе развития научной управленческой мысли одержательная сущность управления организацией как системой в течение длительного времени являлась предметом дискуссии среди научного сообщества. Так, в конце XIX века управление рассматривалось как наука (А. Файоль, Ф. Тейлор и др), в середине XX века стало преобладать мнение о том, что управление - это искусство (например, П. Друкер). И только в начале текущего столетия пришло однозначное понимание, что управление организацией - это сочетание подходов научного управления с искусством влияния на людей.

Последовательное развитие представлений об управлении организацией нашло выражение в различных школах научного управления (таблица 1).

Таблица 1. Развитие системы управления предприятием.

\begin{tabular}{|l|l|}
\hline Научные школы & $\begin{array}{l}\text { Представление об объекте управле- } \\
\text { ния }\end{array}$ \\
\hline Научного управления & Производственный процесс \\
\hline Административная (классическая) & Предприятие \\
\hline Поведенческих отношений & $\begin{array}{l}\text { Предприятие как социально-эконо- } \\
\text { мическая система }\end{array}$ \\
\hline Количественного подхода & $\begin{array}{l}\text { Совокупность процесса производ- } \\
\text { ства и управления }\end{array}$ \\
\hline Системного подхода & Предприятие как открытая СЭС \\
\hline Ситуационного подхода & Предприятие в микро- и макросреде \\
\hline
\end{tabular}

Источник: составлено автором по материалам [1, 2]. 
системы, её оптимального функционирования и развития» $[7$, с. 18].

Серов В.М. в своём учебнике описывает управление организацией так: «это функция организованных систем различной природы, обеспечивающая сохранение их определённой структуры, поддержание режима деятельности, реализацию их целей и программ»,

- «процесс воздействия субъекта на все то, что он пытается подчинить своей воле, изменить, преобразовать, направить на достижение поставленных целей» $[8$, с. 27].

В.М. Васильев излагает: «управление производством - наука о формах и методах преобразования материальных и технических ресурсов, труда людей и информационной технологии в конечную продукцию в соответствии с поставленной целью при условии учёта воздействия внешней среды на элементы производства» [9, с. 21]. Макареня Т.А. представляет управление как систему, которая состоит из субъекта, объекта, целей, прямых и обратных связей: «Управление - это непрерывный процесс воздействия субъекта управления на объект управления для достижения целей при наименьших затратах времени и ресурсов» [10, с. 301].

Из сказанного выше, авторы особо отмечают, что при управлении одни объекты влияют на другие и это влияние взаимно и реализует цели предприятия. Процесс управления проводится с помощью принятия и осуществления управленческих решений руководителями и их осознанием работниками. В результате сотрудничества субъекта и объекта управления осуществляется приём, сообщение, перерабатывание и исследование информации в том и другом направлении.

Процедура управления предполагает слаженную работу, которая и гарантирует в итоге реализацию всех целей, которые стоят перед предприятием. Для регулирования деятельности существует особый орган, который реализует работу управления. На любом предприятии выделяются управляющая и управляемая части [11].

С этой точки зрения, управление можно рассматривать как процесс воздействия управляющей стороны на объект управления, целью которого выступает стремление к определённому результату.

Управляющая часть - административно-управленческий аппарат; управляемая часть - совокупность производственных и функциональных подразделений, осуществляющих производственный процесс.

Административно-управленческий аппарат осуществляет управленческие решения как итог разбора, прогнозирования, повышения эффективности, экономического доказательства и подбора возможностей из большого количества разновидностей результата поставленной цели. Управленческое решение принимается, чтобы преодолеть возникшие препятствия, это результат командного творческого труда.

Управляемая часть - это различные производственные и функциональные подразделения, занятые обеспечением производственного процесса.

В настоящее время любое предприятие постоянно испытывает значительные воздействия изменяющейся внешней среды. Воздействия могут быть разные: конкуренты начали производить ту же самую услугу по новой технологии с меньшими издержками; появилась новая аналогичная услуга, обеспечивающая у потребителя больший эффект; изменился курс валют; инфляция обесценила всю полученную прибыль и др. Средствами управления в таких неустойчивых условиях важно обеспечить гибкость предприятия, его адаптивность и эффективную приспособляемость, способность оперативно реагировать на вызовы внешней среды.

В этих условиях правомерно говорить о формировании новой парадигмы управления организацией. Экономическая категория «парадигма» введена в научный оборот Т. Куном, который под парадигмой подразумевал признанные всеми научные достижения, дающие научному сообществу в течение определённого времени модель постановки проблем и их решений [12].

С этой позиции, парадигму управления следует рассматривать как структуру суждений на управление, которые вытекают из основных и научных взглядов крупных учёных и признанных другими исследователями и практиками в сфере управления.

Заметим, что парадигма управления, как и любая система, находится в постоянном развитии, в котором принято выделять четыре основных этапа: [13]

- кризис - зарождается, когда парадигма управления перестаёт адекватно отвечать на вызов внутренней и внешней среды;

- революция;

- зарождение новой парадигмы;

- закрепление и признание новой парадигмы управления.

Современная парадигма управления использует не только устоявшиеся элементы (власть, авторитет, мотивация), но и новые (командообразование, управление знаниями, инновационность). Новая парадигма управления - реальные ответы на вызовы времени, быстрые и подчас непредсказуемые изменения внешней среды. Адаптация, приспособляемость стали жизненно важными необходимыми свойствами любой организации. Новая парадигма управления основана на инновациях, на использовании знаний. Сравнительные характеристики 
традиционной и «новой» парадигмы управления представлены в таблице 2.

\begin{tabular}{|c|c|}
\hline $\begin{array}{l}\text { Традиционная парадигма } \\
\text { управления }\end{array}$ & Новая парадигма управления \\
\hline $\begin{array}{l}\text { Предприятие - закрытая } \\
\text { система, цели, задачи и условия } \\
\text { деятельности которой достаточно } \\
\text { стабильны }\end{array}$ & $\begin{array}{l}\text { Предприятие - открытая со- } \\
\text { циально-экономическая система, } \\
\text { рассматриваемая в единстве } \\
\text { факторов внешней и внутренней } \\
\text { среды }\end{array}$ \\
\hline $\begin{array}{l}\text { Главный фактор успеха и конкурен- } \\
\text { тоспособности - рост масштабов } \\
\text { производства товаров и услуг }\end{array}$ & $\begin{array}{l}\text { Ориентация на качество товаров и } \\
\text { услуг, на удовлетворение потреби- } \\
\text { телей, а не на объёмы выпускае- } \\
\text { мой продукции }\end{array}$ \\
\hline $\begin{array}{l}\text { Главная задача управления } \\
\text { — рациональная организация } \\
\text { производства, эффективное ис- } \\
\text { пользование всех видов ресурсов } \\
\text { и повышение производительности } \\
\text { труда. Превалирует управление } \\
\text { функционированием }\end{array}$ & $\begin{array}{l}\text { Ситуационный подход к управ- } \\
\text { лению, признание быстроты и } \\
\text { адекватности реакции, обеспечи- } \\
\text { вающей адаптацию к условиям } \\
\text { существования организации, при } \\
\text { которых рационализация про- } \\
\text { изводства становится второсте- } \\
\text { пенной. Управление развитием, } \\
\text { инновациями }\end{array}$ \\
\hline $\begin{array}{l}\text { Главный источник прибавочной } \\
\text { стоимости — производственный } \\
\text { рабочий и производительность } \\
\text { его труда }\end{array}$ & $\begin{array}{l}\text { Главный источник прибавочной } \\
\text { стоимости — люди, обладающие } \\
\text { знанием, и условия реализации их } \\
\text { потенциала }\end{array}$ \\
\hline $\begin{array}{l}\text { Система управления, построенная } \\
\text { на контроле всех видов деятельно- } \\
\text { сти, функциональном разделении } \\
\text { труда, стандартах и правилах } \\
\text { исполнения }\end{array}$ & $\begin{array}{l}\text { Система управления, ориенти- } \\
\text { рованная на повышение роли } \\
\text { организационной культуры и } \\
\text { нововведений, на мотивацию } \\
\text { работников и стиль руководства }\end{array}$ \\
\hline $\begin{array}{l}\text { Управление традиционными фак- } \\
\text { торами производства - землёй, } \\
\text { трудом и капиталом }\end{array}$ & $\begin{array}{l}\text { Управление не только традицион- } \\
\text { ными факторами, но и знаниями }\end{array}$ \\
\hline $\begin{array}{l}\text { А. Файоль, Ф. Тейлор, А. Маслоу } \\
\text { и др. }\end{array}$ & $\begin{array}{l}\text { П. Друкер, И. Ансофф, Т. Питерс } \\
\text { и др. }\end{array}$ \\
\hline
\end{tabular}

Источник: составлено автором на основе [14].
Под воздействием изменяющейся социально-экономической практики постоянно видоизменяется парадигма управления, поскольку она не является устоявшейся теорией и соответствующей схемой постановки проблем, и их решения. Она трансформируется по мере изменения в практике управления.

Парадигму управления следует определить как исходное ценностно-целевое образование, соединяющее воедино организацию на каждом этапе её существования. С точки зрения теоретических положений, разработанных Т. Куном, парадигма управления представляет собой системное образование, которое «не сводимо к логически атомарным компонентам [12, с. 35]»

Подводя итог изложенному, выделим особенности современной парадигмы управления организацией:

1. Организация как объект управления является открытой социально-экономической системой, рассматриваемой в единстве факторов внутренней и внешней среды.

2. Главным конкурентным преимуществом организации являются люди, то есть возрастает потребность в человеческих ресурсах, которые обладают ключевыми знаниями и компетенциями.

3. Необходимым условием развития организации становится создание и реализация эффективной системы мотивации работников для реализации их потенциала.

4. Система управления ориентирована на стимулирование использования информационно-коммуникационных технологий, развитие персонала.

5. В условиях информационной экономики для обеспечения эффективной работоспособности необходимо обеспечение слаженной командной работы.

Таким образом, современная парадигма управления организацией в основе системы управления рассматривает человеческую деятельность и факторы повышения её эффективности.

\section{ЛИТЕРАТУРА}

1. Кузнецов Ю.В. Теория организации: учебник/ Ю.В. Кузнецов, Е.В. Мелякова. - М.: Юрайт, 2015. - 365с

2. Фрейдина Е.В. Исследование систем управления: уч.пособие. - М.: Омега - Л, 2008. - 367 с

3. Тейлор Ф.У. Принципы научного менеджмента. - М.: Контроллинг, 1998.

4. Файоль А. Общее и промышленное управление// Управление - это наука и искусство/ А. Файоль, Г. Эмерсон, Ф. Тейлор, Г. Форд. Москва: Республика, 1992. - c. 9-12.

5. Peter F. Drucker. A New Discipline, Success! - New York: Harper Collins, 1987

6. Кравченко А.И. Социология менеджмента. М.:ЮНИТИ, 1999.

7. Основы социального управления/ под ред. Проф. В.Н. Иванова. - М.: Высш.шк., 2001

8. Серов В.М., Нестерова Н.А., Серов А.В., Организация и управление в строительстве. - М.: Издательский центр «Академия», 2008.

9. Васильев В.М., Панибратов Ю.П., Резник С.Д., Хитров В.А., Управление в строительстве: Учебник для вузов. - СПб.: СПбГАСУ, 2001.

10. Экономика, организация и управление на предприятии /А.В. Тычинский и др.; под ред. М.А. Боровской. - Ростов н/Д.: Феникс, 2010. 
11. https://center-yf.ru/data/Menedzheru/upravlenie-organizaciey.php

12. Кун Т. Структура научных революций. М.: АСТ, 2003. - 605 с.

13. Коробейникова Е.В. Парадигма управления как системная социально-психологическая характеристика организации// Вестник Нижегородского университета им. Н.И. Лобачевского. - 2009. - № 1. - с. 294-300

14. Захарова Л.Н. Парадигма управления как организационное основание работы психолога на предприятии// Materially IV mezinarodni prakticka conference «Evropska veda XXI stoleti - 2008». 16-31 kvetna 2008. Praha: Publishing House «Education and Science». Dil 9. P. 30-33.

(c) Озина Альбина Михайловна (al.ozina@mail.ru), Бузмакова Алёна Николаевна (a.n.buzmakova@mail.ru),

Хачатрян Аревик Врежовна (arevik_hachatryan@mail.ru).

Журнал «Современная наука: актуальные проблемы теории и практики»

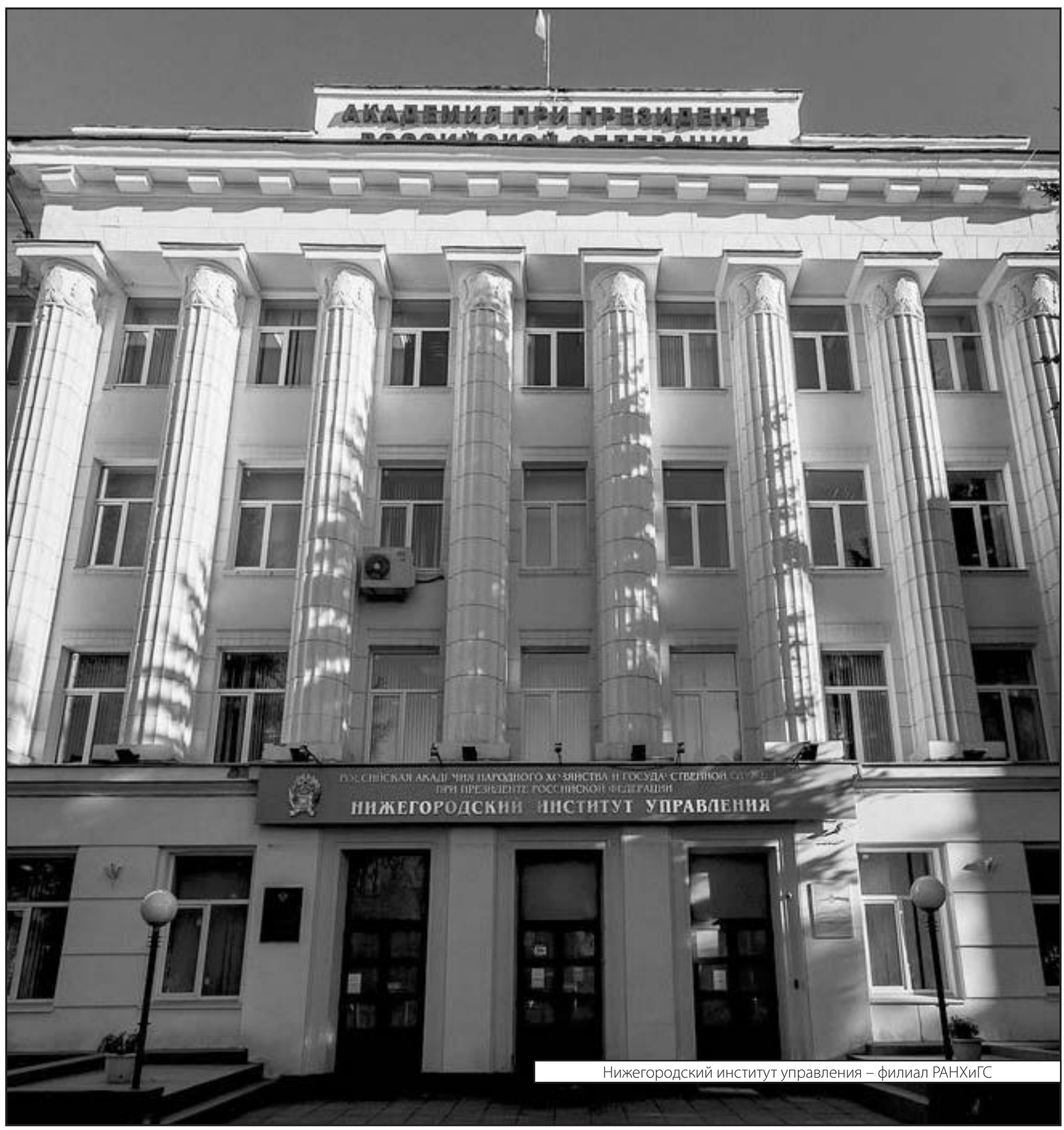

